\title{
Psychogeriatrics in England: Its Route to Recognition by the Government as a Distinct Medical Specialty, c.1970-89
}

\author{
CLAIRE HILTON * \\ Institute of Psychiatry and Consultant Old Age Psychiatrist, Fairfields House, \\ Roe Green, Kingsbury, London NW9 0PS, UK
}

\begin{abstract}
Demographic trends, and older people over 65 years disproportionately occupying beds in psychiatric hospitals, pointed to their increasing clinical needs. Clinical work with older people often required different skills from work with younger people. 'General psychiatrists', nominally working with adults of all ages, usually had little interest in working with older people. By 1977, it was clear to clinical leaders in the field of psychogeriatrics that official recognition of their specialty by the government was essential to ensure service development. Official recognition would provide the means to collect data to identify gaps in services, to obtain information on the implementation of government guidance and to advocate for resources, including ensuring high quality training posts for doctors wanting to specialise in the field. Doctors have traditionally taken the lead in creating new medical specialties, and psychogeriatrics was no exception. However, support fluctuated towards the specialty from the leadership of the Royal College of Psychiatrists. Health service leaders who did not undertake work with older people, were incredulous that others wished to do so. Negotiations between the Royal College of Psychiatrists and the Department of Health and Social Security about recognising psychogeriatrics were convoluted and prolonged. Recognition was achieved in 1989, following intervention by the Royal College of Physicians of London.
\end{abstract}

Keywords: Psychogeriatrics, Department of Health and Social Security, Royal College of Psychiatrists, Royal College of Physicians, Mental illness, Old age

\section{Introduction}

In 1989 I was a very junior psychiatrist at Withington Hospital, Manchester. One morning, the senior consultant old age psychiatrist, Dr David Jolley, came bounding up the back stairs to the offices on the third floor of the old workhouse block which housed the

* Email address for correspondence: claire.hilton@ nhs.net

I am grateful to Professors Tom Arie and Pat Thane and to the anonymous reviewers for their constructive comments. 
'psychogeriatric' wards. He announced exuberantly: 'We are a specialty! We are a specialty!' I wondered what he meant: we were doing the work, weren't we? I was too embarrassed to ask, but it whetted my appetite to find out. He was celebrating the recognition of psychogeriatrics ('old age psychiatry' or mental health services for people over 65 years), ${ }^{1}$ as a specialty by the Department Health and Social Security (DHSS). His exuberance related to the long and convoluted struggle to achieve this, the subject of the present study.

This paper focuses on the tortuous administrative processes, largely involving the 'psychogeriatricians', the Royal College of Psychiatrists (RCPsych) and the DHSS, to achieve specialty recognition, rather than the demographic challenges or the development of clinical knowledge which was rooted in earlier decades. However, some understanding of these issues, and of the process of medical specialisation more generally, are important to understand the subsequent events. They are outlined in the introduction. Patients, their families and staff working specifically with older people could see the benefits of the new methods. ${ }^{2}$ Convincing the authorities was more challenging.

This study contributes to the historiography of old age in the twentieth century. Social, financial and economic aspects of old age have been tackled by some historians. ${ }^{3}$ Fewer have explored physical health provision in old age. ${ }^{4}$ The development of mental health services for older people has been almost untouched by historians. Lack of historiography perhaps reflects the tendency of historians of medicine to marginalise older people in their studies, ${ }^{5}$ reflecting a broader, and ongoing, marginalisation of older people which is central to the theme of this paper.

\section{Medical Specialisation}

Increasing medical knowledge and technological changes, associated with the need for particular clinical skills, stimulate specialisation. The development of new medical specialties is usually medically led, revolving round accurate diagnoses and clinical interventions, the core work of a physician. The medical profession might also have been helped to take a creative lead in service development because it was securely established in society and was male dominated. This contrasted with other professions, such as nursing and social work, which were regarded as lower status and were largely female-dominated. Other factors such as public demand, clinicians' interest and financial rewards, ${ }^{6}$ and the perceived balance of specialist and generalist skills required by the hospitals also contributed to the process.

1 'Old age psychiatry' and 'psychogeriatrics' were used interchangeably from the early 1970s. There was discussion, but no decision, about which should be the official term. 'Psychogeriatric services' meant the broad spectrum of hospital and community psychiatry for older people with all types of mental illnesses. The term 'psychogeriatrics' is used in this paper (except in quotations and titles) because that was its designation in 1989 when it achieved official recognition.

2 Catherine Colwell, 'Out for the Day', Bethlem Maudsley Hospital Gazette, 1 (1954), 182-3.

${ }^{3}$ For example, Pat Thane, Old Age in English History: Past Experiences, Present Issues (Oxford: Oxford University Press, 2000); Robin Means and Randall Smith, The Development of Welfare Services for Elderly People (Kent: Croom Helm, 1985).

${ }^{4}$ Moira Martin, 'Medical Knowledge and Medical Practice: Geriatric Medicine in the 1950s', Social History of Medicine, 7 (1995), 443-61.

${ }^{5}$ For example, Edward Shorter, A History of Psychiatry: From the Era of the Asylum to the Age of Prozac (New York: John Wiley, 1997); Roy Porter, Madness: A Brief History (Oxford: Oxford University Press, 2002).

${ }^{6}$ George Rosen, 'Medical Thought and the Rise of Specialism', Ciba Symposia, 11, 2 (1949), 1126-34 1126. 
In England, eye hospitals, 'lying-in' hospitals, 'asylums', hospitals for 'sick children', and a hospital for 'Fistula and other Diseases of the Rectum' developed in the nineteenth century. ${ }^{7}$ Tensions developed between specialists and generalists, ${ }^{8}$ but by the 1920 s, the medical profession accepted that specialisation was necessary and inevitable. ${ }^{9}$ Particularly in state-provided health services, a fluctuating economic climate might also affect government commitment to recognise new specialties, especially if they focused on chronic disorders in undervalued sectors of the population and required additional resources. $^{10}$

Psychiatric specialisation emerged alongside that for physical illnesses. The Royal Medico-Psychological Association (RMPA), the professional body of psychiatrists, established 'Committees' for psychotherapy and learning disability psychiatry in 1927, for child psychiatry in 1943, and for forensic psychiatry in $1963 .{ }^{11}$ The RMPA became the RCPsych in 1971 and the Committees became 'Sections'. New clinical interests led to the formation of special interest 'Groups', smaller and of lower hierarchical status than the Sections, but indicating increased interest and knowledge, precursors of specialisation.

The emergence and recognition of new clinical specialties is administratively complex. It necessitates various interactions, such as with the government, with university medical schools and teaching hospitals, and with bodies responsible for ensuring high standards of clinical work, including training schemes and professional examinations (in the United Kingdom (UK), the medical Royal Colleges).

\section{Older People: The Knowledge Base and Demographic Background}

Some medical practitioners in the nineteenth century acknowledged that older people had medical needs for which their doctors required specific knowledge and skills. ${ }^{12}$ Concerns paralleled those about illness in childhood; children and older people had distinct illness presentations and treatment requirements, different from young and middle-aged adults. ${ }^{13}$ Thus the need for modified clinical approaches across the lifespan was recognised well before the period explored in this paper, but for older people, clinically beneficial changes in practice were rare.

Among professionals and public, the belief prevailed that poor health in older people was inevitable and irreversible and therefore not worthy of the attention of the medical profession. That shifted slightly in the 1940s, following reports in the prestigious British Medical Journal $(B M J)^{14}$ and The Lancet ${ }^{15}$ demonstrating that improved outcomes could be achieved through accurate diagnosis, cautious but adequate treatment and rehabilitation,

\footnotetext{
${ }^{7}$ Lindsay Granshaw, St Mark's Hospital London: A Social History of a Specialist Hospital (London: King Edward's Hospital Fund for London, 1985).

${ }^{8}$ George Rosen, The Specialisation of Medicine with Particular Reference to Ophthalmology (New York: Froben Press, 1944), 67.

${ }^{9}$ Rosemary Stevens, Medical Practice in Modern England: The Impact of Specialisation and State Medicine (New Haven, CT, and London: Yale University Press, 1966) 38.

${ }^{10}$ Julian Tudor Hart, 'The Inverse Care Law', The Lancet, 297 (1971), 405-12.

${ }^{11}$ Information by courtesy of Francis Maunze, archivist RCPsych, April 2014.

12 George Day, A Practical Treatise on the Domestic Management and Most Important Diseases of Advanced Life (London: T. and W. Boone, 1849); Francis Anstie, 'On Certain Nervous Affections of Old Persons', Journal of Mental Science, 16 (1870), 31-41.

${ }^{13}$ Malford Thewlis, Geriatrics: A Treatise on Senile Conditions, Diseases of Advanced Life, and Care of the Aged (St Louis, MO: C.V. Mosby, 1919), 7.

${ }^{14}$ Marjory Warren, 'Care of Chronic Sick', British Medical Journal, 2 (1943), 822-3.

15 Marjory Warren, 'Care of the Chronic Aged Sick', The Lancet, 2 (1946), 841-3.
} 
and allowing older people more time to recover from illness. In addition, in old age, unlike in younger people, physical and psychiatric illnesses and frailty commonly coexist, creating different diagnostic and treatment challenges. This was also observed in the 1940s. ${ }^{16}$

A handful of 'geriatricians', keen to improve the heath of older people, established the Medical Society for the Care of the Elderly (MSCE, later British Geriatrics Society, BGS) in $1947 .{ }^{17}$ The specialty of geriatric medicine, was officially recognised in 1948 at the inception of the National Health Service (NHS), followed by a gradual increase in consultant appointments and development of services. ${ }^{18}$ Reports of benefit from psychiatric interventions for older people were also published in the mid 1940s. However, these were less robust than for geriatric medicine and appeared in less influential journals. ${ }^{19}$ Also, psychiatrists were ambivalent towards working specifically with older people. ${ }^{20}$ There were no developments parallel to geriatric medicine for older people's mental health.

From the 1950s onwards, mental health services were changing in Britain and other western countries. New effective medications and more liberal mental health legislation contributed to gradually closing custodial psychiatric hospitals, giving way to community services with psychiatric departments incorporated into general hospitals. ${ }^{21}$ Younger people, thought to be more likely to respond to treatment, were prioritised for the new approaches. ${ }^{22}$ Although there were more older people in the population, the government prioritised the well-being of younger people in order to compensate for the population imbalance, rather than promoting older people's health and welfare. ${ }^{23}$ Nevertheless, in 1950, the Ministry of Health proposed assessment services and improvements in longterm care for 'the aged suffering from mental infirmity' ${ }^{24}$ Little implementation followed; evidence is lacking that the government actively encouraged the psychiatrists or the authorities.

Concern was also prompted by the rising number and proportion of older people in mental hospitals. In 1948, almost $25 \%$ of patients in the mental hospitals were over $65,{ }^{25}$ when $11 \%$ of the general population were that age. In 1964, people over 65 occupied over $40 \%$ of beds in six regional health administrative areas and over $33 \%$ in the other nine

16 James Affleck, 'Psychiatric Disorders among the Chronic Sick in Hospital', Journal of Mental Science, 94 (1948), 33-45.

17 J. Grimley Evans, 'Geriatric Medicine: A Brief History', British Medical Journal, 315 (1997), 1075-7: 1076.

18 John Brocklehurst, The Geriatric Day Hospital (London: King Edward's Hospital Fund, 1970) 17. There were about 240 consultant geriatricians in the UK 1974 compared to 30-40 psychogeriatricians. Tom Arie and David Jolley, 'Psychogeriatrics', in H. Freeman (ed.), A Century of Psychiatry (London: Mosby-Wolfe, 1999) 260-5: 262.

${ }^{19}$ Felix Post, 'Some Problems Arising from a Study of Mental Patients over the Age of 60 Years', Journal of Mental Science, 90 (1944), 554-65; Aubrey Lewis and Helen Goldschmidt, 'Social Causes for Admission to a Mental Hospital for the Aged', Sociological Review, 35 (1943), 86-98.

20 104th Annual Meeting of the RMPA, September 1945, Journal of Mental Science, 92 (1946), Supplement: 14. 193.

${ }^{21}$ Ministry of Health, A Hospital Plan for England and Wales, Cmnd. 1604 (London: HMSO, 1962) 6.

22 Denis Martin, Adventure in Psychiatry (Oxford: Bruno Cassirer, 1962).

${ }^{23}$ William Beveridge, Social Insurance and Allied Services, Cmd. 6404 (London: HMSO, 1942) 92; Pat Thane, 'The Debate on the Declining Birth-Rate in Britain: The "Menace" of an Ageing Population, 1920s-1950s', Continuity and Change, 5 (1990), 283-305.

${ }^{24}$ Ministry of Health, Care of the Aged Suffering from Mental Infirmity, HMC(50)25 (1950).

${ }^{25}$ Ministry of Health, memo, 'Care of the aged' (SAC(MH)(49)4) MH 133/502 Para 3 (National Archives); Office of Health Economics (OHE), 'UK resident population and projections by age group, 1948-2051' http://www.ohe.org/page/health-statistics/access-the-data/demographics/data.cfm accessed 17 June 2013. 
areas mainly on long-stay wards (from $12 \%$ of the population). ${ }^{26}$ Increased institutional care partly reflected age-related degenerative disorders and the needs of ageing longstay patients with illnesses dating back many years, but these factors were unlikely to account fully for this trend. Stereotypical pessimism, concerning improving the mental health of older people, in hospitals and in society more broadly, probably contributed to their receiving mainly custodial care. Outpatient treatment was rare; when community psychiatric assessments were undertaken it was frequently with a view to long-term admission. $^{27}$

The first comprehensive mental health service 'for the aged' opened in Dumfries, Scotland, in 1958, led by psychiatrist Ronald 'Sam' Robinson. It demonstrated benefits of active treatment and influenced provision south of the border. ${ }^{28}$ The service was based on geriatric medicine practice and on research in the 1950s indicating clinical principles for the diagnosis and treatment of older mentally ill people. This knowledge was based mainly on the work of two psychiatrists in England, Dr Felix Post and Professor Sir Martin Roth. Post's long term follow-up studies of older people with depressive illness and schizophrenia indicated their potential for recovery. ${ }^{29}$ Roth classified mental disorders in old age, identifying five main types. ${ }^{30}$ His findings challenged the widely held assumption that the only psychiatric disorder in older people was inevitably hopeless 'senile dementia'. The new evidence was regarded sceptically ${ }^{31}$ and was not implemented in a systematic or widespread way. Introducing changes in clinical practice required a major cultural shift from earlier entrenched ideas, ${ }^{32}$ which was not forthcoming.

Despite benefit from clinical interventions, geriatric methods were rarely taught in medical schools and rarely inspired psychiatrists. The latter was perhaps associated with the slow rate of change in mental hospitals, perceived challenge to established psychiatric practice by clinical innovations, ${ }^{33}$ and the marginalisation of older people. Fixed retirement ages, financial constraints of living on a pension and a focus on youth culture reinforced marginalisation. Raised awareness of this marginalisation was highlighted with the terms 'gerontophobia' and 'ageism', coined in the late 1960s. ${ }^{34}$ Ageism is difficult to understand, since, unlike many other sorts of discrimination, for example, concerning gender, sexual orientation, race and religion, it relates to our own lives in the future. However, ageism remained prevalent among clinicians and in the

\footnotetext{
${ }^{26}$ Ministry of Health, The Activities of Psychiatric Hospitals: A Regional Comparison: Mental Hospitals and Units 1964 (Statistical Report Series No. 3) (London: HMSO, 1968), 8; OHE, op. cit. (note 25).

${ }^{27}$ Brice Pitt, in C. Hilton (ed.), Guthrie Trust Witness Seminar 2008: The Development of Old Age Psychiatry in Britain 1960-1989 (University of Glasgow, 2009) 17. http://www.gla.ac.uk/media/media_196526_en.pdf accessed 30 June 2013.

${ }^{28}$ Russell Barton, foreword in Anthony Whitehead, In the Service of Old Age: The Welfare of Psychogeriatric Patients (Harmondsworth: Penguin Books, 1970) 9-10.

${ }^{29}$ Felix Post, 'Geriatric Unit', Bethlem Maudsley Hospital Gazette, 1 (1955), 270-1; Felix Post, The Significance of Affective Symptoms in Old Age: A Follow-Up Study of 100 Patients (London: Oxford University Press, 1962); Felix Post, Persistent Persecutory States of the Elderly (Oxford: Pergamon Press, 1966).

${ }^{30}$ Martin Roth, 'The Natural History of Mental Disorders in Old Age', Journal of Mental Science, 101 (1955), 281-301.

${ }^{31}$ Geriatric Committee of the Research and Clinical Section of the RMPA, 'Report to Council on the course and outcome of mental disorders in old age' (1957) 1 (RCPsych Archives).

32 Joshua Carse et al., 'A District Mental Health Service: The Worthing Experiment' The Lancet, 1 (1958), $39-41$.

33 Ibid.

${ }^{34}$ Alex Comfort, 'On Gerontophobia', Medical Opinion and Review, 3, 9 (1967), 30-7; Robert Butler, 'Age-Ism: Another Form of Bigotry', Gerontologist, 9 (1969), 243-146.
} 
public perception. When people become old they may adopt the stereotypes, attitudes and expectations themselves. ${ }^{35}$

Pat Thane has noted that public concern about older people focused more on poverty, pensions and employment rights, and much less on inequalities in health and social care. ${ }^{36}$ Dedicated geriatric and psychogeriatric services aimed to alleviate existing health inequalities by providing clinical interventions to older people, delivered by enthusiastic staff who took an interest in them and who expected to achieve therapeutic benefit. Their low-tech clinical practices had to compete for NHS resources against more highly regarded, often high-tech, interventions, usually for acute conditions. High-tech interventions, such as in cardiology or replacing a hip joint, often produce dramatic and easily measurable improvements, ${ }^{37}$ and were prioritised over low-tech for funding. ${ }^{38}$ Low-tech, such as medico-psycho-social approaches which restored an older person with depression to good health or enabled a person with dementia to live contentedly at home, received less. All were miraculous clinical interventions devised in the mid-twentieth century, but the latter two were under-valued compared to the first two. In part that can be explained by high-tech innovations being anticipated by Western society and being readily adopted and funded compared to low-tech innovations, which often require a psychological mind-shift of professionals and public, and often take years. ${ }^{39}$

Arguably, government policy-makers should have ensured adequate services for older people in the light of evidence of their increasing numbers and needs, and the demonstrable benefits of clinical interventions. ${ }^{40}$ When effective schemes, reducing hospital bed use and supporting people at home, were reported in the $1960 \mathrm{~s},{ }^{41}$ Ministry spokesmen were unenthusiastic, stating that those successes would not be reproducible elsewhere. ${ }^{42}$ When services for children and older people competed for the same pot of money, older people lost. ${ }^{43}$

Rhetoric was full of good intentions, ${ }^{44}$ but that did not align with availability of resources to support dedicated health care for older people. For example, in 1977/8 the Cabinet acknowledged that, for older people, 'Important needs are going unmet' ${ }^{45}$ Deeprooted negative stereotypes probably contributed to under-provision. Negative perceptions of inevitably declining health in old age were common in professional and lay circles ${ }^{46}$

\footnotetext{
${ }^{35}$ Becca Levy, 'Stereotype Embodiment: A Psychosocial Approach to Ageing', Current Directions in Psychological Science, 18 (2009), 332-6: 333.

36 Pat Thane, 'Older people and equality', in P. Thane (ed.), Unequal Britain (London: Continuum. 2010) 7-28. 14-16.

${ }^{37}$ R.M. Rosser and V.C. Watts, 'The Measurement of Hospital Output', International Journal of Epidemiology, 1 (1972), 361-8.

38 Report by the Public Expenditure Survey Committee, Part 2: Detailed Analysis of Programmes and Supplementary Analyses. Cabinet papers, 4 July 1977, CAB 129/197/3111 (National Archives).

${ }^{39}$ Leon Eisenberg, 'The Relationship between Psychiatric Research and Public Policy', British Journal of Psychiatry, 153 (1988), 21-9: 28.

40 Post, Significance and Persistant Persecutory States, op. cit. (note 29).

41 Anthony (Tony) Whitehead, 'A Comprehensive Psychogeriatric Service', The Lancet, 2 (1965), 583-6.

42 John Brothwood, 'The organisation and development of services for the aged with special reference to the mentally ill', in David Kay and Alexander Walk (eds.), Recent Developments in Psychogeriatrics: A Symposium (London: RMPA, 1971) 99-112: 110.

43 Public Expenditure Survey Committee, op. cit. (note 38), 109.

44 DHSS, A Happier Old Age: A Discussion Document on Elderly People in our Society (London: HMSO, 1978).

45 Public Expenditure Survey Committee, op. cit. (note 38), 111.

46 Melanie Henwood, 'No sense of urgency: age discrimination in health care', in E. McEwen (ed.), Age: The Unrecognised Discrimination: Views to Provoke Debate (London: Age Concern England, 1990) 43-57: 43-4.
} 
with little evidence of shift during the period under study. ${ }^{47}$ Stereotypical beliefs that active treatment was ineffective and stigmatising language, such as labelling older unwell people as hospital 'bed blockers', ${ }^{48}$ could be associated with reduced staff interest in treating older people and prevent improvements in well-being. Although some negative expectations of health in old age are accurate, relentless decline into dependency is not. A joint geriatric, psychiatric and nursing report in 1987 commented: 'the low worth of old people and their therapeutic potential still persist despite the dramatic evidence to the contrary' ${ }^{49}$ 'Stigma by association', the phenomenon of attaching negative characteristics of the disadvantaged group to those supporting them,${ }^{50}$ might have undermined provision and discouraged staff from working with older people. In the 1980s at the Bethlem-Maudsley Hospital, for example, nurses on the psychogeriatric ward were known as 'shit shovellers' by their colleagues. ${ }^{51}$ In 1985, Thomas Bewley, president of the RCPsych, highlighted the stigma associated with the work:

it was quite difficult to discover what percentage of a psychiatrist's sessions were spent on caring for old people, part of the problem being that the general psychiatrist might have fears about being labelled as a psychogeriatrician. ${ }^{52}$

\section{Leading Service Development from c.1970 and into the 1980s}

A pattern established during the 1950s and 1960s of the government intermittently appearing to encourage psychogeriatric clinical work, ${ }^{53}$ while failing to recognise the specialty or provide necessary resources, continued into the 1970s ${ }^{54}$ High profile scandals of NHS hospital care in the 1960s highlighted that older people frequently received inaccurate diagnoses, inadequate treatment and poor quality care. ${ }^{55}$ The World Health Organisation's report, Psychogeriatrics, in 1972, emphasised the need for widespread and adequate services for older people based on the 'epidemiology, origin, prevention, development and treatment' of psychiatric disorders in old age. ${ }^{56}$ It also expressed disappointment at the generally inadequate implementation internationally of their earlier recommendations. ${ }^{57}$ No evidence has been found at the National Archives or in other sources that the UK government paid serious attention to either set of recommendations.

\footnotetext{
${ }^{47}$ BGS/RCPsych/Royal College of Nursing, Improving Care of Elderly People in Hospital (London: RCN, 1987) 5 .

48 David Hall and Bill Bytheway, 'The Blocked Bed: Definition of a Problem', Social Science and Medicine, 16 (1982), 1985-91.

49 BGS/RCPsych/Royal College of Nursing, op. cit. (note 47).

${ }^{50}$ Simon Olshansky, 'Stigma: Its Meaning and Some of its Problems for Vocational Rehabilitation Agencies', Rehabilitation Literature, 26 (1965), 71-4.

51 Jim Birley, 'Psychogeriatrics: The Smell of Success or the Odour of Chronicity?' International Journal of Geriatric Psychiatry, 2 (1987), 131-4: 131.

52 Planning meeting for RCP/RCPsych joint working party, 25 September 1985, MS4811 (Royal College of Physicians Archives).

53 For example Ministry of Health, HMC(50)25 op. cit. (note 24); Enoch Powell, opening speech in Emerging Patterns for the Mental Health Services and the Public: Proceedings of a Conference at Church House, Westminster, 9-10 March 1961 (London: NAMH, 1961), 5-10.

${ }^{54}$ For example, DHSS, Psycho-Geriatric Assessment Units, HM (70)11 (London: HMSO, 1970).

55 Barbara Robb, Sans Everything: A Case to Answer (London: Nelson, 1967).

56 World Health Organisation (WHO), Psychogeriatrics (Geneva: WHO, 1972) 11.

57 WHO, Mental Health Problems of Aging and the Aged (Geneva: WHO, 1959).
} 
By 1969, there were still fewer than ten dedicated old age mental health services nationally. 58

In the late 1960s, a handful of new psychogeriatricians began to organise clinical services in their own localities. In the early 1970s, psychogeriatrics underwent a transition, from individuals, working in relative isolation in their own localities, to creating a clinical network. The psychogeriatricians established a 'coffee house' group to exchange views, offer mutual support and consider ways to improve their services, ${ }^{59}$ since, despite growing clinical expertise, how to organise and deliver widespread effective psychogeriatric services was not a given. Members of the group included: Brice Pitt (London Hospital, Mile End); Loic Hemsi and James Cockburn (Long Grove, Epsom); Carrick McDonald (Warlingham Park, Surrey); Klaus Bergmann and Garry Blessed (Newcastle upon Tyne); Anthony (Tony) Whitehead (Brighton); and Tom Arie (Goodmayes, Ilford) ${ }^{60}$

The group had similar objectives to the BGS. Considering that potential benefits of treatment in both physical and psychiatric illness in old age were identified twentyfive years earlier, it is surprising that psychogeriatrics took so much longer than its physical illness counterpart to reach the stage of forming a nucleus of interested consultants. The almost religious enthusiasm of the early BGS, 'engaged upon a crusade on behalf of our forgotten but deserving patients', ${ }^{61}$ resembled the fervour of the new psychogeriatricians: 'a happy band of pilgrims'. ${ }^{62}$ Enthusiasm was intense and unpredicted. ${ }^{63}$ It expressed an important sentiment: treating mentally ill older people could be a rewarding career. Enthusiastic psychiatrists joined geriatricians to set out ideas for widespread, comprehensive psychogeriatric services. ${ }^{64}$

In 1972, the coffee house group 'heavily influenced' ${ }^{65}$ the development of the DHSS memorandum Services for Mental Illness Related to Old Age (HM(72)71), ${ }^{66}$ a blueprint for future services. Typically, this followed a year behind a DHSS circular which mainly concerned younger mentally ill people. ${ }^{67}$ The coffee house group also realised that, if they were to make a significant impact, they would have to increase their numbers and acquire a body through which they could find a voice. The required quorum for an official RCPsych Group was achieved and the Group for the Psychiatry of Old Age (GPOA) was inaugurated on 9th February $1973 .{ }^{68}$ Its purpose (although not explicitly stated during the early meetings) was to promote good practice by sharing experiences, developing services, fostering education, encouraging research, exerting pressure on government and other bodies, and commenting on all matters relating to mental health in old age. ${ }^{69}$ The Group worked within the RCPsych, including aiming to establish training programmes for the

58 Arie and Jolley, op. cit. (note 18); Tom Arie, 'Martin Roth and the "psychogeriatricians", , in K. Davidson and A. Kerr (eds.), Contemporary Themes in Psychiatry: A Tribute to Sir Martin Roth, (London: Gaskell, 1989) 231-8.

${ }^{59}$ GPOA, minutes, 9 February 1973, 2 (RCPsych Archives).

60 Tom Arie, op. cit. (note 58) 233.

61 Trevor Howell, ‘The Origins of the British Geriatrics Society', Age and Ageing, 3 (1974), 69-72: 72.

62 Brice Pitt, interview by author (2006).

63 Tom Arie, 'Morale and the Planning of Psychogeriatric Services' British Medical Journal 3 (1971), 166-70: 170.

${ }^{64}$ M. David Enoch, and John Howells, The Organisation of Psychogeriatrics (Ipswich: SCP, 1971) 11.

65 Tom Arie, interview by author (2004).

66 DHSS, Services for Mental Illness Related to Old Age, HM(72)71 (London: HMSO, 1972).

${ }^{67}$ DHSS, Hospital Services for the Mentally Ill, HM(71)97 (London: HMSO, 1971) 1.

68 GPOA, minutes, 9 February 1973, 2 (RCPsych Archives).

69 GPOA, 'Draft memorandum on the readiness of the group for the Psychiatry of Old Age now to become a section of the Royal College of Psychiatrists' (c.October 1977) (RCPsych Archives). 
specialty, and forged outside links with people, including policymakers, geriatricians, nurses and social workers, to develop age-appropriate services. The GPOA was the only national body campaigning for better services for older mentally ill people. Other organisations, for example, the Alzheimer's Disease Society ${ }^{70}$ was founded in $1979,{ }^{71}$ while Age Concern and Help the Aged (now Age UK) had no specific mental illness focus. Special interest group status within the RCPsych did not confer any authority or standing as a specialty.

In 1978 , approximately 20,000 beds ( $25 \%$ of total) were occupied by people over 75 years $^{72}$ (drawn from $5.3 \%$ of the general population), ${ }^{73}$ an upwards trend which was expected to continue. ${ }^{74}$ Some factors which seemed to contribute were hard to justify. For example, the tendency for hospitals to prioritise younger people for community and rehabilitation services ${ }^{75}$ was perhaps related to stereotypical views of the impossibility of recovery in older people and to younger people's perceived future economic potential, if they achieved sufficient recovery to enable them to (re)-enter paid employment, a yardstick of success in Western society and an outcome unlikely for pensioners. Other explanations for more older in-patients include: clinically unnecessary admissions; patients remaining in hospital when they no longer required treatment and could have been supported better elsewhere; limited provision of community residential care and domiciliary services; unsupported families being unable to cope with their care; ${ }^{76}$ treatable conditions such as depressive illness remaining undiagnosed. ${ }^{77}$ In localities where psychogeriatricians established teams, psychiatric hospital bed occupancy was a useful measure of clinical success. Their interventions dramatically reduced long-stay admissions, above the rate suggested by the illness epidemiology, thus supporting the view that factors other than the illness affected bed use. This justified the psychogeriatricians clinical approach and reinforced their enthusiasm. ${ }^{78}$ Psychogeriatricians had positive expectations of treating older people, accurately distinguishing and treating the various and multiple disorders which occur, and devising medico-psycho-social interventions tailored to their needs in the community. These hallmarks of their specialty emerged through empirical observation, service evaluations, publications and discussion with colleagues. They were supporting older people to be as independent as possible in the community instead of living in institutions. Arie commented on the interest of general psychiatrists who were unable, or unwilling, ${ }^{79}$ to do this; they: "cannot formulate a "psychogeriatric" problem in any other terms but as the need to get it instantly off their hands'. ${ }^{80}$

\footnotetext{
70 Alzheimer's Society since 1999.

${ }^{71}$ Alzheimer's Society, 'Our History' http://www.alzheimers.org.uk/site/scripts/documents_info.php?document $\mathrm{ID}=81$ accessed 30 April 2013.

72 DHSS, A Happier Old Age: A Discussion Document on Elderly People in our Society (London: HMSO, 1978) 36.

73 OHE, op. cit. (note 25).

${ }^{74}$ Felix Post and Tom Arie, 'Training: consultant manpower' Report for RCPsych Manpower Committee, 24 September 1974 (Peter Jefferys archives).

75 Martin, op. cit. (note 22).

${ }^{76}$ Klaus Bergmann et al., 'Management of the Demented Elderly Patient in the Community', British Journal of Psychiatry, 132 (1978), 441-9: 447-8; Whitehead, op. cit. (note 28).

77 Tony (Anthony) Whitehead, cited in Anon. 'Aged "could be spared misery", , Guardian, 7 October 1974, 6.

78 Arie, op. cit (note 63), 3 (1971), 166-70: 170.

${ }^{79}$ Garry Blessed, in summary of views about specialty recognition (c.1977) (Tom Arie archives).

${ }^{80}$ Tom Arie, 'Dementia in the Elderly: Diagnosis and Assessment', British Medical Journal, 4 (1973), 540-3: 541.
} 
Thus a distinct body of clinical knowledge and practice began to emerge, core features of a new specialty. More clinical teams were established. Pitt commented in 1974: 'colleagues who argue that it [psychogeriatrics] should not exist are in no stronger a position than Canute holding back the waves' ${ }^{81}$

Even with $\mathrm{HM}(72) 71$, consistent government support for steady psychogeriatric service development was not forthcoming although it gave the clinician-campaigners a basis for persisting with negotiations, centrally and locally. With little government support by 1974, the GPOA queried: 'Is the DHSS aware of, and prepared to condone the inadequacy of services?' They requested a meeting with the DHSS. ${ }^{82}$ An informal meeting ${ }^{83}$ concluded:

The Department thanked the Group for joining in the interesting discussion. They would welcome further proposals from the College on the holding of a joint Conference on the psychiatric services for old people after the publication of the White Paper. ${ }^{84}$

Merely having an 'interesting discussion' gave the impression that the DHSS was condescending towards the psychogeriatricians and their objectives. An official conference was postponed until after the publication of 'the White Paper' in 1975, which was mainly concerned with mental illness in younger adults. ${ }^{85}$ Their services were also slow to improve, but planning for older people lagged behind younger, again. Jolley commented that the DHSS listened to the Group, ${ }^{86}$ but at times it did 'not quite' understand its concerns. ${ }^{87}$ A senior DHSS representative usually attended their meetings, ${ }^{88}$ so overt criticism may have risked harming that relationship. ${ }^{89}$

Throughout the 1970s and ' $80 \mathrm{~s}$, using funding redirected from existing resources, more consultant psychogeriatrician posts were advertised by local health authorities, ${ }^{90}$ suggesting acknowledgment that benefits accrued from the services they provided. Official data on numbers of psychogeriatricians leading teams were not available to support these observations: they were subsumed under the label 'general psychiatrists'. Psychogeriatricians carried out their own studies to ascertain for themselves staff numbers, types and extent of services provided and in which localities. ${ }^{91}$ At the end of 1986, about $70 \%$ of the population of the UK had a specialist psychogeriatric service available to them. Most full-time consultants were supported by junior medical staff, and had a mean of twenty-one assessment and seventy-four long-stay beds, plus twenty-five 'day places'. ${ }^{92}$ From twelve consultant psychogeriatricians in 1970, there were 120 in 1980 and 280 in 1989. ${ }^{93}$

${ }^{81}$ Brice Pitt, preface to Psychogeriatrics: An Introduction to the Psychiatry of Old Age (Edinburgh: Churchill Livingstone, 1974).

82 Brice Pitt to Morris Markowe (Registrar, RCPsych), letter, 17 May 1974 (Peter Jefferys archives).

83 GPOA, minutes, 13 June 1974, 2.b. (RCPsych Archives).

84 GPOA/DHSS, meeting, 21 June 1974, 3, MH 150/812 (National Archives).

85 DHSS, Better Services for the Mentally Ill Cmnd. 6233 (London: HMSO, 1975).

${ }^{86}$ David Jolley, e-mail, 18 May 2007.

${ }^{87}$ GPOA, minutes, 6 May 1976, 7.i. (RCPsych Archives).

88 GPOA, meeting attendance lists (RCPsych Archives).

${ }^{89}$ GPOA, minutes, 10 October 1973, 2.a.v. (RCPsych Archives).

${ }^{90}$ David Jolley, 'England Expects: More than We Can Provide', Psychiatric Bulletin, 13 (1989), 248-9.

91 John Wattis et al., 'Psychogeriatrics: A National Survey of a New Branch of Psychiatry', British Medical Journal, 282 (1981), 1529-33.

92 RCP/RCPsych, Care of Elderly People with Mental Illness: Specialist Services and Medical Training (London: RCP/RCPsych, 1989) 3.

93 Arie and Jolley, op. cit. (note 18) 262. 
The UK was ahead of other countries including those in Western Europe and North America. ${ }^{94}$ The UK model of psychogeriatrics (and of geriatrics), linking primary care, acute hospital treatment, community and long-term care, based on research and facilitated by the structure of the welfare state, was internationally regarded as effective and appropriate for treating and supporting older people. ${ }^{95}$ Alongside NHS services, the presence of psychogeriatricians in UK universities had the potential to influence recognition; ensuring dedicated time and expertise for research and teaching gave academic credibility to the discipline. Arie was appointed Professor of Health Care of the Elderly in 1977, in Nottingham, ${ }^{96}$ and took a lead role in subsequent negotiations concerning recognition of the specialty. Several chairs of psychogeriatrics were established in the 1980s. The first academic journal in the subject, the International Journal of Geriatric Psychiatry, originated in the UK in 1986, edited by Elaine Murphy, Professor of Psychogeriatrics at Guy's Hospital, London. ${ }^{97}$ There is no evidence to indicate that international and academic standing directly influenced DHSS recognition. However, the confidence it gave to the psychogeriatricians perhaps bolstered their determination to achieve it.

\section{Recognition until 1980: Mainly Establishing a Psychogeriatric Foothold within the Royal College of Psychiatrists}

It was not inevitable in the early 1970s that the discipline would become a separate specialty. At the first meeting of the GPOA, the need for separate specialty status was discussed. The question was asked, but not answered, whether old age was a separate specialty like child psychiatry, or the work of a general psychiatrist with a particular interest in old age..$^{98}$

Over the next few years, psychogeriatricians held various opinions on the need for official specialty status, although this did not split an otherwise unified group of clinicians intent on providing adequate clinical services. Post held the opinion, that clinically, there was no need for a separate specialty: illnesses in old age might present differently but this was part of a continuum and there was no clear dividing line between middle and old age. Psychogeriatrics lay within general psychiatry, he stated, and the only reason for separate recognition was to ensure adequate training and facilities, a political need. Blessed was concerned that separate status would result in professional isolation 'from the general body of unwilling psychiatrists who wish to reject the elderly' but he acknowledged that recognition might help in demarcating areas of responsibility. Pitt commented that the specialty already existed de facto and the College should inform the DHSS of that. ${ }^{99}$

\footnotetext{
${ }^{94}$ Kenneth Shulman, 'The Future of Geriatric Psychiatry', Canadian Journal of Psychiatry, 39, 8 (1994), Supplement 1: S4-S8.

95 For example, William Barker, 'Hospital-based geriatric services in Great Britain: implications for the US' (1983) (British Geriatrics Society Archives); Helen Chiu, ‘A View from Hong Kong', Old Age Psychiatrist, 53 (2011), 38.

96 Tom Arie, interviewer Elaine Murphy, 'A Conversation with Tom Arie', International Journal of Geriatric Psychiatry, 11 (1996), 671-9: 678.

97 SPOA, minutes; 22 September 1983, 25SPOA/83, (RCPsych Archives).

98 GPOA, minutes, 9 February 1973, 4 (RCPsych Archives).

${ }^{99}$ Felix Post, Brice Pitt, Garry Blessed, quoted in summary of views about specialty recognition (c.1977) (Tom Arie archives).
} 
The GPOA struggled to get the 'voice' of psychogeriatrics heard within the RCPsych by influential senior colleagues, and by the DHSS. ${ }^{100}$ Standards of psychiatric practice for all age groups were 'abysmally low', according to the RCPsych in $1974 .{ }^{101}$ In the light of new ideas and dynamism about psychogeriatrics it is surprising that psychogeriatrics was not rapidly encouraged in order to improve standards in that area. On the other hand, older people were only one of the RCPsych's concerns. With an increasing membership, in 1978 the Group became a Section (SPOA). This gave it greater authority within the RCPsych, including automatic representation on the College Council, but did not noticeably improve interest among psychiatrists at the top of the College hierarchy.

The DHSS overlooked the adequate resourcing of services for older mentally ill people, despite their own recommendations. The department stated in 1975 that 'in some districts a psychiatrist with a special responsibility for the elderly has been appointed and there may be advantages in this arrangement', ${ }^{102}$ and in 1976 discussions between the DHSS and RCPsych concluded that 'at least one consultant in each district should ... [act] as a focal point for advice and for developing the district's psychiatric services for the elderly'. ${ }^{103}$ However, in 1977, the RCPsych and the DHSS proposed a national increase in the number of consultants in general psychiatry without a mentioning a proportional increase for psychogeriatrics. ${ }^{104}$ This was amended, under pressure from the GPOA. ${ }^{105}$ A DHSS paper (1978) on medical manpower also omitted psychogeriatrics, stating that there should be five consultants in 'adult' psychiatry and one in child psychiatry for a district of 200,000 people. ${ }^{106}$ Proposals may have included some clinical sessions for older people, but made no reference to earlier recommendations.

In 1977, leaders of the discipline realised that official recognition would be essential to create the means to collect data to identify gaps in services, obtain information on the implementation of government guidance, advocate for resources, and to ensure high quality training posts for doctors wanting to specialise in the field. ${ }^{107}$ Existing official data did not show how many people and in which professions provided psychiatric services for older people nor the availability of rehabilitation, domiciliary, district general hospital, day hospital or community services, even after the DHSS had recommended them. ${ }^{108}$ Relevant information often had to be extracted or estimated and was difficult to interpret. ${ }^{109}$ In official documents, potentially useful data were at times subsumed under the title, 'For the elderly (including the elderly mentally infirm)', ${ }^{110}$ giving imprecise indications of requirements and provision for psychogeriatric disorders. The lack of specific data was

100 GPOA, minutes, 30 January 1975, 'reminder notes' 6 (RCPsych Archives).

${ }^{101}$ Manpower Committee, 'Memorandum on psychiatric manpower as it affects the psychiatric services: to be presented to the Central Manpower Committee' (1974) MSC6/74, 1 (RCPsych Archives).

102 DHSS, Better Services, op. cit. (note 85) 31.

103 DHSS/RCPsych meeting, 23 June 1976, 'Psychiatric medical manpower' 7, MH 150/812 (National Archives).

${ }^{104}$ RCPsych, 'Providing a district service for adult psychiatry, its special interests and related specialities medical manpower priorities' (September 1977) EFCC41/77, MSC9/77 (Peter Jefferys archives).

105 Tom Arie to Thomas Bewley, letter, 27 October 1977 (Peter Jefferys archives).

106 DHSS, Medical Manpower: The Next 20 years (London: HMSO, 1978) 22.

107 Tom Arie to Royal Commission on the NHS, letter (draft?) April 1977 (Tom Arie archives).

108 DHSS, HM(72)71, op. cit. (note 66).

109 David Jolley and Tom Arie, 'Organisation of Psychogeriatric Services', British Journal of Psychiatry, 132 (1978), 1-11: 7 .

${ }^{110}$ Ministry of Health, Health and Welfare: The Development of Community Care (Revision to 1975/6) (London: HMSO, 1966) 412. 
acknowledged by Roland Moyle, Minister of State for Health, but without suggestions to remedy the deficit. ${ }^{111}$ The GPOA discussed whether to draw the lack of specialty status to the attention of the Royal Commission on the NHS in 1977. However, the Commission's focus was largely clinical service provision, which in psychogeriatrics was increasing, and it was decided to tackle the status issue through the College. ${ }^{112}$

Among the leadership of the RCPsych, there were undertones of opposition to specialty status for psychogeriatrics and incredulity that colleagues should choose to work in the field. The Manpower Committee minuted disparaging comments that psychogeriatrics might create 'a vacuum for unsuitably qualified people' and 'It was necessary to preserve standards and maintain some unity'. ${ }^{113}$ The main implication of such comments was, in psychogeriatrician Michael White's words, their erroneous belief: 'that psychogeriatrics is a dead-end job for which no psychiatrist in his right mind applies' ${ }^{114}$ It has been difficult to identify statements made by the RCPsych or DHSS at this time which suggest they held alternative, more positive perceptions. These gaps might reflect the systematic 'weeding' of RCPsych archives, which, for example, discarded papers and correspondence attached to minutes. ${ }^{115}$

An illustration of lack of understanding of psychogeriatric enthusiasm and leadership is suggested by the blunder of the Royal College of Physicians of London (RCP) when planning a meeting about psychogeriatrics in 1979. The date coincided with a committee meeting of the SPOA, an arrangement with which the SPOA would never have agreed. ${ }^{116}$ The meeting had been arranged with the RCPsych leadership, rather than directly with the SPOA, making the SPOA angry. ${ }^{117}$ The ignoring of old age specialists was a recurrent problem. It had happened previously, at the Bethlem-Maudsley Hospital, when a report on psychogeriatric services excluded the opinions of Post, the only psychiatrist working there with older people. ${ }^{118}$ It also recalled the position of geriatricians among their physician peers in the early years of geriatric medicine. ${ }^{119}$ These recurrent faux pas suggest that generalists saw themselves as the profession's decision-makers, to the exclusion of old age specialists, who had the hands-on expertise.

The influence of general psychiatrists, well represented in higher tiers of the RCPsych, combined with the DHSS's habit of planning and providing for younger before older people, ${ }^{120}$ perpetuated the neglect of services for older people. However, it is uncertain whether the journey towards recognising psychogeriatrics was any slower than for other under-valued new psychiatric disciplines at this time. This can be illustrated by comparison with substance misuse (drug and alcohol) psychiatry, which became a special interest

${ }^{111}$ Roland Moyle, 'Elderly mentally infirm persons' HC Deb 14 November 1978 Hansard Vol. 958 c201W http://hansard.millbanksystems.com/written_answers/1978/nov/14/elderly-mentally-infirm-persons\#S5 CV0958P0_19781114_CWA_425 accessed 23 September 2012.

112 Tom Arie to Brice Pitt, letter, 29 September 1977 (Tom Arie archives).

113 Manpower Committee, minutes, 20 December 1973, 'Psychogeriatrics as a career' 49/73 (RCPsych Archives).

114 D.M.D. White, 'What's Wrong with Psychogeriatrics?' Psychiatric Bulletin, 3 (1979), 89-90: 89.

115 Information by courtesy of Francis Maunze, archivist, RCPsych, 12 December 2012.

116 SPOA to Sir Douglas Black, letter, 6 February 1979 (Tom Arie archives).

117 SPOA to Desmond Pond, letter, 7 February 1979 (Tom Arie archives).

118 Carlos Blacker, 'Mentally infirm people over 65: need for better means of support and disposal'. BethlemMaudsley Medical Committee, 1 January 1959, MCD7/59 21 (Bethlem-Maudsley Hospital Archives).

${ }^{119}$ British Medical Association, Geriatrics Joint Sub-committee, minutes, 24 February 1954, 4 (BMA Archives).

${ }^{120}$ For example, Robert Cawley, 'Planning for the Future: Report on a Joint Conference by the DHSS and the Royal College of Psychiatrists', News and Notes (RCPsych) (May 1973), 1-5: 4. 
Group in 1978. ${ }^{121}$ This too had had a slow gestation from the first suggestion for specialist clinics in $1943 .{ }^{122}$ Despite proving its worth clinically and providing services, it encountered similar problems within the RCPsych. ${ }^{123}$ As with psychogeriatrics, the Manpower Committee did not envisage consultants specialising in substance misuse full time $^{124}$ and slow development probably reflected sluggish changes in attitudes among professionals, and more widely, towards stereotyped and stigmatised people. Committees consisting largely of senior clinicians in established specialties seemed to project their own clinical dislikes and stereotypes onto emerging disciplines. They perhaps also regarded emerging specialties as a criticism of their own expertise, a challenge faced by clinicians with new interests. ${ }^{125}$

\section{Training the Psychogeriatricians and Specialty Recognition}

Providing specialist training to ensure high quality psychogeriatric clinical leadership was an objective of the GPOA/SPOA. Theoretically, training could progress without specialty recognition, but, in practice, allocation of training posts was inseparable from it. Training issues thus help to illustrate the reasons for the psychogeriatricians' desire for recognition. For example, a discussion about part-time training at senior registrar (SR) level, the specialist training grade prior to consultant appointment, noted a proposed cap on general psychiatry training posts because of a 'national surplus' of trainees in that specialty. Since psychogeriatrics was included under that umbrella, psychogeriatric training would also be reduced $^{126}$ despite a shortage of psychogeriatricians. In essence, training for consultant leadership for a specialty was intimately linked to the recognition of that specialty.

Senior registrar training for psychogeriatrics consisted of one year in psychogeriatrics plus two years in general psychiatry. These posts could be filled by future psychogeriatricians or general psychiatrists. In 1980 the SPOA noted that 250 new consultant psychogeriatricians would be required to fulfil health service workforce targets of one full-time psychiatrist dedicated to older people in each district. ${ }^{127}$ This seemed unrealistic within a reasonable timeframe. With only six or seven ${ }^{128}$ existing SR training posts nationally, even if all posts were full and all SRs holding them finally opted for full-time psychogeriatric careers, there would be only twenty-one more consultants in three years. Sometimes, unrealistic training ideas were put forward by the RCPsych, for example, SRs should be allocated to the most understaffed areas. ${ }^{129}$ That was inappropriate: understaffed areas had few, if any, consultants to provide training, reinforcing the impression that the

121 Thomas Bewley, Madness to Mental Illness: A History of the Royal College of Psychiatrists (London: RCPsych, 2008), 101.

122 British Medical Association: 'The Future of Psychiatry, report of the Group of Practitioners of Psychological Medicine of the British Medical Association' Preliminary (1943) 20 (BMA Archives).

123 RCPsych online archive, 'Substance misuse' 13. http://www.rcpsych.ac.uk/publications/books/rcpp/978190 4671350/extra9781904671350.aspx accessed 4 August 2012.

124 Manpower Committee, minutes, 15 July 1975, MSC13/75, 18/75.b. (RCPsych Archives).

${ }^{125}$ Rosen, Specialisation, op. cit. (note 8) 63, 67; Granshaw, op. cit. (note 7) 428.

126 SPOA, minutes, 28 February 1980, 9EC/80 (RCPsych Archives).

127 SPOA working party, 'Medical manpower in the psychiatric specialties', May 1980 (RCPsych Archives); John Wattis and Tom Arie, 'Further Developments in Psychogeriatrics in Britain', British Medical Journal, 289 (1984), 778. This was probably a UK estimate.

${ }^{128}$ Manpower Committee, minutes, 16 December 1980, 27/80.d.i.; Some sources say 6 existing SR posts and a further 7 to be created, for example: SPOA working party, 'Medical manpower in the psychiatric specialties' May 1980 (RCPsych Archives).

129 Joint Committee on Higher Professional Training, minutes, 14 November 1979, 2.b. (RCPsych Archives). 
specialist nature of psychogeriatrics was under-valued or perhaps poorly understood. In 1980, the College Council constructively recommended that all psychiatric trainees should 'spend a significant amount of their time' working in specialist psychogeriatric units, ${ }^{130}$ which was probably realistic, since about half of all localities across the country then had a consultant psychogeriatrician. ${ }^{131}$ The SPOA welcomed that and proposed that 'significant' should be interpreted as 'a minimum of six months at both registrar and senior registrar level'. It is unclear whether the Council accepted their proposal. ${ }^{132}$

For psychogeriatrics, a further seven temporary, un-funded SR posts each for up to four years, for which Regional Health Authorities would have to bid, were agreed in $1980 .{ }^{133}$ They might provide an extra twenty-eight trained psychogeriatricians at the end of the four-year period. ${ }^{134}$ These seven additional posts would be re-designated from general psychiatry. ${ }^{135}$ Psychogeriatricians thus had no option but to compete against their general psychiatry colleagues for training resources, which was unlikely to ensure mutually helpful working relationships. The situation might have fuelled the general psychiatrists' ambivalence towards the new specialty: they might not want to work with old people but nor did they want their own workforce reduced.

In 1984, the additional temporary posts were judged by the College Manpower Committee to have been 'very effective', ${ }^{136}$ suggesting interest in them by trainees and a willingness by Regional Health Authorities to fund them. DHSS arguments about inevitable recruitment difficulties for the emerging specialty ${ }^{137}$ appeared less strong. Meanwhile, the RCPsych proposed that, to achieve consultant targets in all specialties, SR numbers should be approximately one-fifth of the total required for the consultant grade; ${ }^{138}$ thirteen psychogeriatric training posts was still too low. Eventually, in 1986, the Manpower Committee seemed to recognise some advantages of dedicated SR psychogeriatric training and proposed that general psychiatry might relinquish some of their posts to psychogeriatrics. ${ }^{139}$ There seemed to be a cautious shift in opinion towards psychogeriatrics by this committee, whose members also sat on other influential College committees.

\section{Influences on Recognition: The Geriatric-Psychogeriatric Interface}

Understanding the organisation of geriatric medicine services might shed light on how psychogeriatrics became a separate specialty. Generally there was a mutually supportive working relationship between geriatricians and psychogeriatricians. However, the two specialties did not directly mirror each other in terms of their hospital organisation, so lessons learnt by the DHSS from one might not apply to the other. For example, whereas some physically unwell older patients required referral to specialists other than

\footnotetext{
${ }^{130}$ Gerald Timbury, 'Training in the Psychiatry of Old Age', Psychiatric Bulletin, 5 (1981), 173.

131 Wattiset al., op. cit. (note 91).

132 Timbury, op. cit. (note 130).

133 Manpower Committee, minutes, 6 July 1979, 24/79.b. 'Report of the meeting with the DHSS', 26 June 1979, iii; Manpower Committee, 16 December 1980, 27/80.d.i. (RCPsych Archives).

134 SPOA, Manpower working party, 22 May 1980; SPOA, minutes, 3 December 1981, Shore to SPOA, letter, 37EC/81 (RCPsych Archives).

135 Joint Committee on Higher Professional Training, minutes, 24 November 1979, 2.b. (Peter Jefferys archives).

136 Manpower Committee, minutes, 16 February 1984, 5/84.i. (RCPsych Archives).

137 Elizabeth Shore (DHSS) to Desmond Pond (RCPsych), letter, 20 February 1980, (RCPsych Archives).

${ }^{138}$ Fiona Caldicott, 'The Short Report and Its Implications', Psychiatric Bulletin, 6 (1982), 155-7: 155.

${ }^{139}$ Manpower Committee, minutes, 5 June 1986, 13/86.iv. (RCPsych Archives).
} 
geriatricians, such as cardiologists, gastroenterologists or surgeons, psychogeriatricians aimed to accept all newly referred psychiatric patients above a specified age.

In 1977, the Royal College of Physicians of London (RCP) proposed reintegrating geriatrics into general medicine. ${ }^{140}$ This had the potential to discourage the DHSS from recognising psychogeriatrics as a separate specialty in case a similar debate followed. Most reasons for geriatric reintegration related to difficulties of recruiting to the specialty. An anonymous editorial in The Lancet in 1977 commented that 'bringing geriatrics into the main stream of medicine' might help in 'attracting to the specialty the talent it needs and deserves'. ${ }^{141}$ In 1979, the Royal Commission on the NHS commented that old age work was not an 'attractive category' for full-time clinical specialisation. ${ }^{142}$ That might have reflected the situation in geriatric medicine, but for psychogeriatrics it was contrary to evidence that more doctors were choosing to work in the field. An internal DHSS memo discussing reintegration of geriatric medicine was attached to papers concerning developing psychogeriatric services. ${ }^{143}$ Although this hints that the DHSS linked the two issues, definite conclusions about the impact of the geriatric reintegration question on psychogeriatrics cannot be inferred from a single memo. In particular, internal civil service memos mention many ideas, but their significance in decision-making is variable. No documentation has yet been identified to confirm a direct impact.

Geriatricians shared with psychogeriatricians the experience of fighting for the existence of their specialty. In 1984 a debate at the RCP proposed: 'The care of the elderly is harmed by the specialty of geriatrics' contending that general physicians were as good as specialist geriatricians at looking after older people. ${ }^{144}$ This reflected tensions common to new medical specialties, ${ }^{145}$ and was reminiscent of the complex relationship between general psychiatrists and psychogeriatricians. ${ }^{146}$ The RCP's proposition was not unique, but was compatible with sociological critiques, for example by Stephen Katz, that specific old age services helped to make older people 'inherently separate and inevitably pathological'. ${ }^{147}$ This undesirable outcome, was contrary to the pragmatic aims of geriatricians and psychogeriatricians to improve health and well-being of older people through opportunities for treatment equitable with those for younger people. Also in 1984, the Nuffield Provincial Hospitals Trust, (which supported independent research and policy analysis for improving health care in the UK) commissioned Sir Ivor Batchelor, Professor of Psychiatry at Dundee, to write a critique of DHSS policies for old age. $\mathrm{He}$ included comments on: the low professional status of geriatric medicine despite its clinical success; its 'undistinguished' contribution to research; and the need for 'a more talented intake into the training grades'. ${ }^{148}$ His comments were surprising, for example, criticising the professional group and hardly mentioning their clinical achievement, since clinical work is the raison d'être for the profession. His comment on geriatric research may have

\footnotetext{
${ }^{140}$ RCP, 'Medical Care of the Elderly', The Lancet, 1 (1977), 1092-5: 1094; J. Grimley Evans, 'Integration of Geriatric with General Medical Services in Newcastle', The Lancet, 1 (1983), 1430-3; Pitt, op. cit. (note 27$) 28$.

141 Anon. 'How to Rescue Geriatrics', The Lancet, 1 (1977), 1091.

142 Report of the Royal Commission on the National Health Service Cmnd. 7615 (London: HMSO, 1979) 64.

143 DHSS internal memo, signature illegible, 11 March 1980, MH 154/1328 (National Archives).

144 Anon. 'Care of the Elderly: Is it a Specialty?' The Lancet, 2 (1985), 459.

145 Rosen, Specialisation, op. cit. (note 8) 67.

146 Brice Pitt, interview by author (2006); Pitt, op. cit. (note 27) 18.

147 Stephen Katz, Disciplining Old Age: The Formation of Gerontological Knowledge, (Charlottesville, VA: University Press of Virginia, 1996) 8.

${ }^{148}$ Ivor Batchelor, Policies for a Crisis? Some Aspects of the DHSS Policies for the Care of the Aged: A Commentary (London: NPHT, 1984), 46-7.
} 
reflected rejection-bias by editors of prestigious medical journals because of the subject matter rather than on grounds of scientific rigour, as happened to some psychogeriatric research. ${ }^{149}$ His criticisms may have contained an element of truth, but they perhaps also reflected a broader lack of professional interest in older frail patients or, in Batchelor's words, the 'snobbery of physicians, who have viewed the geriatrician as more often than not a failed physician or at best a physician manqué'. ${ }^{150}$ Snobbery, or stigma by association, might have made senior physicians reluctant to serve older people while stigmatising physicians who did, just like psychiatrists who neither wanted to work with older people nor to support their colleagues in doing so. ${ }^{151}$

Batchelor wrote on psychogeriatrics:

Its practitioners have got off to a good start ... initiatives have come largely from the profession itself .... Psychogeriatrics, which has its own 'head of steam' as a specialty, will be best left to develop in its professional context without much Departmental urging. ${ }^{152}$

This positive stance might be a bias related to his personal interest as a psychiatrist, although he rebuts that possibility. ${ }^{153}$ It suggests that psychogeriatrics was gaining momentum, a view supported by the expansion of services. However, Batchelor's praise did not correspond with his barely lukewarm conclusions: DHSS support for geriatrics and psychogeriatrics should enable them to 'lead, innovate, develop, and research into the services necessary, and establish and teach exemplary high standards of caring and treatment' without providing comprehensive services. ${ }^{154}$ This was unrealistic: effective training in clinical work, a practical discipline, requires an apprenticeship of direct experience in high-quality services, not a theoretical model. Perhaps his unrealistic and impractical conclusion undermined his credibility on what had the potential to be a very damaging document for psychogeriatric development. Archival evidence is lacking, such as in relevant DHSS, RCP and RCPsych minutes, to indicate that Batchelor's report directly influenced decisions on psychogeriatric recognition. However, along with other negative perceptions and concerns, it perhaps added to the DHSS's caution.

\section{Negotiating Recognition with the DHSS}

In 1979, the SPOA requested that the RCPsych Council designate psychogeriatrics as a specialty. It was unequivocally recorded in SPOA minutes that recognition was 'agreed in principle' by Council, but Council stated that the final decision should be left 'to see what the DHSS felt about it' at their joint annual meeting. ${ }^{155}$ This suggested that the College thought that the DHSS had the final veto, although the DHSS indicated that it would 'be likely to be guided by the College on this matter if it endorsed the Section's views'. ${ }^{156}$ The protocol seemed unclear.

A letter to the president of the RCPsych early in 1980 from Deputy Chief Medical Officer (CMO) Dr Elizabeth Shore, gave the DHSS's view:

\footnotetext{
149 Garry Blessed, letter, 7 June 2013.

150 Batchelor, op. cit. (note 148) 47.

${ }^{151}$ Ingeborg Williams, 'Experiences and Reflections of a Newly Retired Psychogeriatrician', SPOA Newsletter, (Summer 1981) 2-11.

152 Batchelor, op. cit. (note 148) 47.

153 Ibid., 2.

154 Ibid., 48.

155 SPOA, minutes, 27 September 1979, 31SPOA/79 (RCPsych Archives).

${ }^{156}$ DHSS/RCPsych, meeting, 27 July 1979, C69/79, EFCC32/79, MH 154/935 (National Archives).
} 
if psychiatrists specialising in the elderly were to emerge as a separate group of specialists this might carry the implication in everyone's mind that they would take over the burden of the provision of psychiatric services for the elderly mentally infirm with the danger that some general psychiatric care would be withdrawn from the elderly. Should the new specialty not prove to be popular the service needs of the elderly might not be met even to the inadequate extent that it is at present.

The creation of any new specialty adds to the already over rigid hospital medical training and manpower structure and makes manpower planning more difficult particularly if the specialty is relatively small ...

We are, highly appreciative to the growing number of psychiatrists who have elected to devote much of their time to this work 157

This letter raised reasonable questions which required a response. However, in other ways it was problematic. Addressing it to the president of the RCPsych may have been standard practice, but it prevented the SPOA from responding directly. The letter was critical and offered no constructive suggestions. Psychogeriatricians were already 'a separate group' taking on the 'burden' of psychiatric service provision for older people in the districts where they were appointed, although they were unlikely to regard it as a 'burden' a pejorative term. The fear that some 'general psychiatric care would be withdrawn', might have been true, but the quality and benefits of that care was debatable: observing it stimulated the psychogeriatricians to develop their own expertise. Administrative concerns by the DHSS were legitimate, but, in the light of clinical achievements, seem excessive.

The observation that more consultants were leading more services ${ }^{158}$ was not fully compatible with the statement that the new specialty might prove unpopular. However, precise historical analysis of the psychogeriatric recruitment argument has so far proved impossible. Failure to distinguish psychogeriatrics from general psychiatry in DHSS data, ${ }^{159}$ and 'weeded' archives at the RCPsych, contribute to this difficulty. It is also conceivable that lack of DHSS recognition might have contributed to any difficulties of recruitment, associated with poorly designed, improvised training and uncertainty about the future of the new specialty. ${ }^{160}$ At times there were insufficient recruits, but the degree of concern from outside the psychogeriatric field may have been extrapolated from geriatric medicine ${ }^{161}$ or other low-prestige psychiatric specialties, such as mental handicap, ${ }^{162}$ or may have reflected the personal opinions of the College or DHSS leadership, possibly projecting their own prejudices onto a field in which they did not want to work.

Shore's letter also stated that

the Department is not wholly happy about the suggestion that the Psychiatry of Old Age be designated as a specialty. I must emphasise that the final decision is one for the profession. ${ }^{163}$

The RCPsych perhaps felt obliged to conform to the first sentence, to maintain its overall constructive working relationship with the DHSS, despite the assurance of the second. Shore's letter was passed to the SPOA with a request that they draft a paper for Council. 'The problem of specialist status in old age psychiatry' stated:

\footnotetext{
157 Shore, 20 February 1980, op. cit. (note 137).

${ }^{158}$ For example, Garry Blessed, 'Psychogeriatrics in the Nearly Frozen North', SPOA Newsletter, (December 1980) 3-4.

159 Manpower Committee, minutes, 16 February 1984, 4/84.iii. (RCPsych Archives).

${ }^{160}$ Manpower Committee, minutes, 21 February 1979, 1/79, 1 (RCPsych Archives).

${ }^{161}$ RCP, op. cit.; Evans, op. cit. (note 140).

162 Joint Committee on Higher Professional Training, minutes, 23 July 1980, 2.a.; Manpower Committee, minutes, 25 October 1973, 38/73 (RCPsych Archives).

163 Shore, 20 February 1980, op. cit. (note 137).
} 
A reconsideration of our position has become necessary in order to respond to the letter ... from Dr E Shore on behalf of the DHSS. There is no doubt reading the letter as a whole that the DHSS would not wish to see any disturbance of the status quo, ... the case for specialisation is diluted with faint praise and the case against is more positively stated...

It is regretted that Dr Shore's letter so long awaited fails to discuss in any detail ... technical problems [for example, collecting statistics, providing resources] or offers any help in coming nearer to a solution. ${ }^{164}$

Like the College's earlier response, the SPOA's response was perhaps written in order not to upset the RCPsych/DHSS relationship. Subsequently Henry Yellowlees, the CMO, commented: 'I am relieved that the College has rejected a new specialty!' 165 The College's handling of the situation appeared politically motivated.

Through 1979 and 1980 the DHSS and the RCPsych played ping-pong with psychogeriatrics. Earlier historical analysis of how medical specialties develop, almost inevitably upsetting established practices and destabilising relationships, ${ }^{166}$ seemed apposite. A further attempt was made by the SPOA to obtain official, relevant data, without specialty recognition. The DHSS acknowledged the data deficit in June $1981^{167}$ but failed to remedy it at the annual DHSS/RCPsych meeting a month later. ${ }^{168}$

The Conservative government's policy was expressed in the 1981 White Paper Growing Older: 'The increasing needs of increasing numbers of older people simply cannot be met wholly - or even predominantly by public authorities or public finance.' ${ }^{169}$ Written answers to the House of Commons reinforced that Growing Older was 'intended to provide a stimulus to thought and action throughout the community'. ${ }^{170}$ These political imperatives were unlikely to encourage the government to recognise the new clinical specialty, which would require resourcing. Evidence that psychogeriatric interventions reduced long-stay institutional bed use, and thus had potential to reduce expenditure, was not acknowledged.

\section{Reopening the Recognition Campaign}

The SPOA campaign for recognition was reignited in 1987. John Wattis, SPOA secretary, wrote to the president of the RCPsych, Jim Birley, concerning lack of official data and the need to persuade the DHSS 'to behave in a sensible way' about collecting it. ${ }^{171}$ The concerns were as earlier, ${ }^{172}$ and linked to significant frustration for the psychogeriatricians in their aim to improve services. ${ }^{173}$ Citing support from the Health Advisory Service, the inspectorate for NHS quality standards, Birley proposed that the College initiates moves to define psychogeriatrics as a separate specialty. ${ }^{174} \mathrm{~A}$ clear response from them has so far not been identified. Birley had previously shown interest in services for older people. ${ }^{175} \mathrm{He}$ was a social psychiatrist with a multi-disciplinary, ethical and human

\footnotetext{
164 SPOA, 'The problem of specialist status in old age psychiatry' (1980) EFCC19/80, C32/80 (RCPsych Archives).

${ }^{165}$ Henry Yellowlees to Gerald Timbury, letter, 9 December 1980 (RCPsych Archives).

166 Rosen, op. cit. (note 8) 67.

167 DHSS/SPOA, meeting, 11 June 1981, 3, MH 154/1328 (National Archives).

168 DHSS/RCPsych, meeting, 24 July 1981, 2, MH 154/935 (National Archives).

169 DHSS, Growing Older Cmnd. 8173 (London: HMSO, 1981) 59.

${ }^{170}$ George Young, 'Growing Older' HC Deb 31 March 1981 Hansard Vol. 2 c71W http://hansard.millbanksyste ms.com/written_answers/1981/mar/31/growing-older accessed 30 September 2012.

171 John Wattis to Jim Birley, letter, 11 August 1987 (RCPsych Archives).

172 Arie to Royal Commission, op. cit. (note 107).

173 John Wattis, 'Working party on the care of the elderly mentally ill', 24 February 1988, (RCPsych Archives).

174 Jim Birley, memo, 23 December 1987, EFCC13/88 (RCPsych Archives).

175 Birley, 'Smell of success', op. cit. (note 51).
} 
rights stance. ${ }^{176}$ These factors might have stimulated the SPOA to approach him when he took office in 1987.

Strong feelings about recognition were reflected in a SPOA debate the following year. The turnout for this event in London was impressive: 113 participants, mainly consultant psychogeriatricians, when there were fewer than $280^{177}$ in the entire UK. The vote was 101 in favour of specialty recognition, seven against and five abstentions. ${ }^{178}$ The psychogeriatricians envisaged many advantages, with few administrative drawbacks, ${ }^{179}$ although they acknowledged that some changes would be necessary to restructure general psychiatry training and ensure that psychogeriatric training would be led by psychogeriatricians. ${ }^{180}$ The DHSS position had not shifted: the protocol for collecting data on 'sub-specialties' was: 'they are ignored and the episode is coded under the appropriate main specialty. We have no plans to change this' ${ }^{181}$

Around the time Wattis approached Birley, Sir Raymond Hoffenberg, president of the RCP, established a working party on psychogeriatric services. According to the minutes, it was convened because of senior physicians' anxieties about older, mentally unwell people. ${ }^{182}$ Pitt, then SPOA chairman, expressed this more bluntly, that motivation came from 'disgruntled physicians' desiring to remove demented patients from their wards. However, Hoffenberg who had a long-term interest in human rights and equality and had been an anti-apartheid activist in South Africa, his country of birth, ${ }^{183}$ seemed genuine in his concerns.

Hoffenberg initially chaired the working party, further raising the standing of the discussions. He invited Birley's predecessor, Thomas Bewley, to join, ${ }^{184}$ and he took over as chairman when he finished his term of office as president of the RCPsych. ${ }^{185}$ Both Bewley and Hoffenberg remained committed to the working party so the leadership of both Colleges was represented. However, the main body of the working party consisted of four psychogeriatricians, Tom Arie, Colin Godber, Zoe Slattery and John Wattis, and two geriatricians, John Brocklehurst and Bernard Isaacs. The geriatricians were strong supporters of psychogeriatric services, and alongside the psychogeriatricians, guided the direction of the discussion and compiled most of the report. ${ }^{186}$

The meetings moved away from the SPOA-RCPsych-DHSS stalemate but their content was old ground for the psychogeriatricians. ${ }^{187}$ The objective was 'to implement action on the betterment of care and training in the field of care of the elderly mentally ill' (italics in original), ${ }^{188}$ with the expected outcome that 'any joint report by the RCP and the RCPsych,

\footnotetext{
176 Jim Birley in conversation with Greg Wilkinson, Psychiatric Bulletin, 19 (1995), 33-9.

177 Arie and Jolley, op. cit. (note 18) 262.

178 SPOA, minutes, 16 June 1988, 9SPOA/88 (RCPsych Archives).

179 John Wattis, 'Working party on the care of the elderly mentally ill: service recommendations' (1987) D1JPW12.87 (RCPsych Archives).

180 Tom Arie, 'Should psychogeriatrics be a specialty?' (1988) 4 (RCPsych Archives).

181 Karen Robinson to Rachel Jenkins, DHSS memo, 28 November 1988, MH 154/935 (National Archives).

182 RCP/RCPsych, working party, 15 April 1987, 5 (RCP Archives, MS4811).

183 J.G.G. Ledingham, 'Sir Raymond Hoffenberg' http://munksroll.rcplondon.ac.uk/Biography/Details/5775 accessed 5 September 2014.

184 Thomas Bewley, letter, September 2012.

185 RCP/RCPsych, 15 April 1987, op. cit. (note 182) 3.

186 RCP/RCPsych, working party, January-November 1987 (RCP Archives, MS4811).

${ }^{187}$ Health Advisory Service, The Rising Tide: Developing Services for Mental Illness in Old Age (Sutton: NHS HAS, 1982); RCP/RCPsych, working party, 26 January 1987, terms of reference (RCP Archives, MS4811).

${ }^{188}$ RCP/RCPsych, Care of Elderly People. op. cit. (note 92) 1.
} 
would have a positive impact on the DHSS and related services' ${ }^{189}$ Interestingly, the reintegration of geriatrics into general medicine, and Batchelor's report, did not feature in the minutes; after a lapse of several years, they seemed to be less powerful detractors than might have been predicted.

Hoffenberg was the 'first non-psychogeriatrician on the working party to state that Psychogeriatrics should now be a specialty in its own right', and his endorsement was greatly appreciated by the psychogeriatricians. ${ }^{190}$ Recognition as a specialty was recommended in order to facilitate service developments, education, training and research, and was justified by the number of consultants and service patterns (largely based on surveys by Wattis ${ }^{191}$ ), training requirements and the body of knowledge and research, ${ }^{192}$ endorsing reasons proposed previously by the SPOA.

The RCP probably contributed to the low media coverage when the working party's report, Care of Elderly People with Mental Illness, was published. The RCP had recently hosted a press briefing for a report on neonatal medicine which, Hoffenberg revealed, 'got presented in such a distorted way in the press that day and led to an outburst from the Secretary of State'. ${ }^{193}$ There was concern that the same might happen for this jointly published report on psychogeriatrics. Hoffenberg damningly stated:

If the press come ... they will turn it into a Government-bashing session ... They will latch onto the fact that the elderly mentally ill have not been well looked after and might easily manoeuvre us into the position of appearing to blame the Government. ${ }^{194}$

This indicated a clear message, similar to that of the RCPsych in its response to Shore's letter in 1980: ${ }^{195}$ Royal Colleges were reluctant to risk offending the government. Whether as reality or excuse, Hoffenberg stated: 'I am worried that the report does not have enough in it to justify the calling together of a large number of representatives of the press'. ${ }^{196}$ It was therefore unsurprising that, despite being relevant to the health of a large sector of the population, the report received little coverage in the national press. The Guardian cited it on pages eight and twenty-six. ${ }^{197}$ The press also overlooked subsequent Department of Health recognition, noted in the House of Commons on 4th April 1989: 'Psychogeriatrics has been established recently as a separate specialty and there are plans to collect manpower figures in the future'. ${ }^{198}$

The composition of the working party, with a preponderance of old age specialists, probably ensured that the psychogeriatricians' arguments received a dispassionate hearing. The joint endorsement by the RCP and RCPsych was impossible for the DHSS to ignore. Neither the SPOA nor the RCPsych appeared to have sufficient clout to achieve this alone, which raises questions about the authority of the psychiatric leadership generally in the wider medico-political scene at that time.

${ }^{189}$ RCP/RCPsych, op. cit. 26 January 1987 (note 187) 2.

190 Colin Godber to Raymond Hoffenberg, letter, 1 November 1988 (RCP Archives, MS4811).

191 John Wattis, 'Geographical Variations in the Provision of Psychiatric Services for Old People', Age and Ageing, 17 (1988) 171-80; RCP/RCPsych, Care of Elderly People, op. cit. (note 92) 3, 23.

192 Ibid 21.

193 Raymond Hoffenberg to Jim Birley, letter, 8 December 1988 (RCP Archives, MS4811).

194 Raymond Hoffenberg to Jim Birley, letter, 24 November 1988 (RCP Archives, MS4811).

195 Shore, 20 February 1980, op. cit. (note 137).

196 Hoffenberg, 24 November 1988, op. cit (note 194).

197 David Brindle, 'More Psychiatrists Urged for Elderly', Guardian, 24 February 1989, 8; Anon. 'Caring Questions', Guardian, 24 February 1989, 26.

198 David Mellor, 'Psychogeriatrics' HC, Hansard, 4 April 1989, Col. 80 http://www.publications.parliament.uk /pa/cm198889/cmhansrd/1989-04-04/Writtens-6.html accessed 15 June 2011. 
Although some RCPsych committees had shown some shift in attitude, there is no evidence from committee minutes that enthusiasm for the specialty increased generally in the College. Not all psychiatrists welcomed the new specialty. Professor David Goldberg (knighted 1996), appeared to show little interest when specialty status for psychogeriatrics was announced at the RCPsych Manpower Committee, stating that his main concern was the difficulty of providing services with limited resources for the largest group of mentally ill patients, adults under $65 .{ }^{199}$ Undoubtedly, younger people also had difficulty accessing services, ${ }^{200}$ but Goldberg could have stated that resource issues applied to everyone. His response resembled earlier patterns: prioritise younger over older, despite clinical and humane arguments that equitable and age-appropriate services were required.

\section{Discussion}

I only fully understood Dr Jolley's jubilation at achieving government recognition when this research revealed consistent negativity from most colleagues outside geriatrics and psychogeriatrics. There was little positive to find to balance it, despite extensive research in sources such as government papers which I had hoped, perhaps naively, would be logical, evidence-based and neutral. Opposition among general psychiatrists related to lack of clinical interest in older people and unwillingness to treat them or share resources with the psychogeriatricians. Bureaucratic inflexibility in the DHSS was another obstacle, such as being unable to collect specific data before the specialty was recognised. Pervasive negative attitudes towards work with older mentally ill people probably meant that neither the DHSS nor the RCPsych could envisage psychogeriatrics as a stimulating, rewarding career. It was therefore too risky to support. Notably, two medical Royal Colleges were cautious about how much they might advocate for the specialty in case their actions upset their relationship with the DHSS. If Colleges might hinder recognition due to conflicts of interest, this highlighted an awkward situation for under-resourced, under-valued and un-recognised specialities.

The government had to balance various competing interests. For older mentally ill people, rhetoric rather than responsibility prevailed, despite evidence that health improvement could be gained from accurate diagnosis and active treatment. The tendency to regard chronic illness of older people as a social problem continued, with an emphasis on social care from statutory and voluntary services. Expectations of, and for, older people remained low. Innovative medico-psycho-social methods which challenged widespread and firmly held beliefs and time-honoured practice encountered resistance or incredulity among senior doctors, including in the RCPsych and in government. Treating illnesses in older people was neither a political or social priority. Building up from a position of under-provision to a point sufficient to provide widespread and noticeable improvements in health and well-being for older people within a single parliamentary term, and thus impress voters, seemed unlikely. Stigma by association seemed to link the patients, practitioners and the services; all three could be ignored. Negative cultural beliefs, appeared to affect practices of policy makers, politicians, public and health service professionals. The RCPsych showed little identifiable change in attitude: if the RCP had not intervened, recognition might have taken even longer to achieve.

\footnotetext{
199 Manpower Committee, minutes, 14 February 1990, 5.a. (RCPsych archives).

${ }^{200}$ House of Commons Social Services Select Committee, Community Care with Special Reference to Adult Mentally Ill and Mentally Handicapped People, Vol. 1 (London: HMSO, 1985) xxii-xxiii.
} 
Recognition was an important landmark. It brought the desired objectives of better resourced training schemes and more service-focused data. But those improvements could not overcome other problems, such as continuing ageist attitudes, necessitating fighting for resources, ${ }^{201}$ and the tendency of governments to plan and provide for younger before older people. ${ }^{202}$ Mary Marshall, a social scientist, commented in 1990: 'We have to challenge and defeat ageist attitudes in Britain today so that older people can feel proud to be old'. ${ }^{203}$ Existential and psychological theories relating to ageing and ageism ${ }^{204}$ may help to explain the recurring and hardly changing attitudes towards providing psychogeriatric services until 1989, with little evidence of improvement since. ${ }^{205}$ In 2014, staff committed to NHS mental health services for older people still feel undercurrents of ageism when competing for NHS resources and identify with the struggles of their predecessors.

\footnotetext{
201 Williams, op. cit. (note 151); GPOA, 'Group into Section?’ c. 1977, 3 (Peter Jeffreys archives).

202 Department of Health, National Service Framework for Older People (London: Department of Health, 2001).

203 Mary Marshall, 'Proud to be old', in McEwen (ed.), op. cit. (note 46) 28-42: 42.

204 Levy, op cit. (note 35).

205 David Anderson et al., "Mental Health Service Discrimination against Older People', The Psychiatrist, 37 (2013), 98-103.
} 